\title{
СОВРЕМЕННЫЕ ЗДОРОВЬЕСБЕРЕГАЮЩИЕ ТЕХНОЛОГИИ В ДОУ
}

\section{Кириченко Оксана Михайловна}

МБДОУ №24 «Родничок»

\begin{abstract}
Аннотация: Одним из направлений деятельности современного дошкольного учреждения является сохранение здоровья дошкольников. Для этого используются здоровьесберегающие технологии, предполагающие совокупность педагогических, психологических и медицинских действий, направленных на защиту и обеспечение здоровья, формирование ценного отношения к нему. Пандемия естественным образом повлияла на наш образ жизни, а самое главное на наше здоровье. Ограниченная свобода в первую очередь в вопросе двигательной активности, отсутствии физических нагрузок на молодой растущий организм.
\end{abstract}

Ключевые слова: Здоровьесберегающие технологии; эпидемиологическая обстановка; сохранение здоровья дошкольников.

\section{MODERN HEALTH-SAVING TECHNOLOGIES IN DOW}

\section{Kirichenko Oksana Mikhailovna}

Abstract: One of the activities of a modern preschool institution is to preserve the health of preschoolers. For this purpose, health-saving technologies are used, assuming a set of pedagogical, psychological and medical actions aimed at protecting and ensuring health, forming a valuable attitude to it. The pandemic has naturally affected our way of life, and most importantly, our health. Limited freedom primarily in the matter of motor activity, lack of physical exertion on a young growing organism.

Key words: Health-saving technologies; epidemiological situation; preservation of preschool children's health.

Здоровьесберегающие технологии - формирование осознанного отношения ребенка к здоровому образу жизни как ведущей ценности, мотивации к здоровому образу жизни.

Основные задачи здоровьесберегающих технологий:

- обеспечить условия для физического и психологического благополучияздоровья всех участников воспитательно-образовательного процесса;

- формировать доступные представления и знания о ЗОЖ, пользе занятий 
физическими упражнениями, об их основных гигиенических требованиях и правилах;

- реализовать системный подход в использовании всех средств и форм образовательной работы с дошкольниками для своевременного развития жизненно важных двигательных навыков и способностей детей;

- оказывать всестороннюю помощь семье в обеспечении здоровья детей и приобщению их к здоровому образу жизни. [4, с. 6]

Классификация здоровьесберегающих технологий в дошкольном образовании определяется по доминированию целей и решаемых задач, а также ведущих средств здоровьесбережения и здоровьеобогащения субъектов педагогического процесса в детском саду.

Физкультурно-оздоровительные.

Задачи: физическое развитие и укрепление здоровья ребенка технологии развития физических качеств, закаливания, дыхательной гимнастики.

Технологии:

- двигательный режим дошкольников; (И.А. Аршавский);

- подвижные и спортивные игры; (М.А. Васильева, Т.С. Комарова);

- утренняя гимнастика; (Картотека по М.А. Васильевой);

- физкультурные занятия;

- закаливание; ( ходьба босиком по ортопедическим дорожкам, обтирание тела, воздушные, солнечные ванны);

- спортивные развлечения, праздники; «Ловкие и смелые», «Эстафеты», «Богатыри», «Кто быстрее»;

- День здоровья; «Мама, папа, я - спортивная семья»;

- СМИ (ситуативные малые игры - ролевая подражательная имитационная игра);

-Ритмопластика; Г.С. Абрамова «Гимнастика с оздоровительной направленностью»;

- бодрящая гимнастика; (физминутки «Доброе утро» «Стали дети в круг» «Мы веселые ребята»;

- стретчинг; (Упражнения предназначены для растягивания мышц Т.И. Осокина, Е.А. Тимофеева);

- динамические паузы;

- подвижные и спортивные игры; Е.Н.Вавилова «Развивайте у дошкольников ловкость, силу, выносливость»;

- релаксация; М.А.Доронина «Роль игр в физическом воспитании». 
Технологии эстетической направленности:

- гимнастика пальчиковая; ( Пособие Л.П. Савина, Е. С. Анищенкова);

- гимнастика для глаз; «Часы», «Веселый мяч», «Отдыхалочка», «Солнышко» по методике Э.С. Аветисова, Г.А. Шичко, В.Ф. Базарного;

- гимнастика дыхательная; (Пособие Е.В.Пантелеева);

- гимнастика, бодрящая; гимнастика, корригирующая;

- гимнастика ортопедическая; М.С. Норбекова « Дорожка здоровья», «Цветочная азбука», В.К. Алябьева « Нескучная гимнастика».

3. Технологии обучения здоровому образу жизни:

- физкультурное занятие; Л.И. Пензулаева физкультурное занятие направлены на то, чтобы научить детей ориентироваться в пространстве, действовать сообща в играх, проявлять индивидуальные качества;

- проблемно-игровые (игротреннинги и игротерапия, коммуникативные игры, занятия из серии «Здоровье»;

- самомассаж; Л.П.Абрамова, Т.Ю.Бардышева «Орешек на ладошке»;

- точечный самомассаж; Н.А.Белая Руководство по лечебному массажу;

Коррекционные технологии обеспечения социально-психологического

благополучия ребенка. [1, с. 32]

Задачи: обеспечение психического и социального здоровья ребенка, эмоциональной комфортности и позитивного психологического самочувствия ребенка в процессе общения со сверстниками и взрослыми в детском саду и семье.

Технологии:

- специально организованные встречи, игровые тренинги с детьми;

- релаксация; Г.Н.Казакова, Ю.В.Царева «Сборник упражнений»;

- фонетическая ритмика; (Система двигательных упражнений, в которых различные движения (корпуса, головы, рук, ног) сочетаются с произнесением определенного речевого материала (фраз, слов, слогов).

Реализацией данных технологий занимается психолог, а также воспитатель и специалисты дошкольного образования в текущем педагогическом процессе ДОУ.

- арттерапия; (Естественный и бережный метод исцеления и развития души через художественное творчество);

- технологии музыкального воздействия:

сказкотерапия;

- технологии воздействия цветом;

технологии коррекции поведения: 
- психогимнастика; Е.А. Алябьева, М.И.Чистякова «Методическое пособие»;

- фонетическая и логопедическая ритмика;

Педагогическая технология активной сенсорно-развивающей среды.

Задачи: системная совокупность и порядок функционирования всех личностных инструментальных и методологических средств, используемых для достижения педагогических целей.

Технологии:

- использование настольной конторки (работа в режиме смены динамических поз), пейзажного панно (ситуационно-образное моделирование);

- наглядного материала на сенсорно-дидактической подвеске;

- сенсорно-дидактическом держателе (переключение зрения детей с ближних целей на дальние).

Активная сенсорно-развивающая среда, окружающая дошкольника в ДОУ, обеспечивает не только безопасную жизнедеятельность, но и способствует укреплению здоровья и закаливанию детского организма. Удовлетворять врожденную потребность детей в движении, которое служит важным условием формирования всех систем и функций детского организма, одним из способов познания мира, ориентировки в нём, а также средством всестороннего развития дошкольника.

Технологии просвещения родителей. [5, с. 9]

Главными воспитателями ребенка являются родители. Здоровье детей зависит не только от особенностей их физического состояния, но и от условий жизни в семье, санитарной и гигиенической культуры людей, уровня развития здравоохранения и образования, социально-экономической и экологической ситуации в стране.

Детский сад является отправной точкой просвещения родителей. Формы взаимодействия с родителями разнообразны, они могут быть как индивидуальные и групповые, так и традиционные и нетрадиционные.

Задачи: оказывать просветительскую помощь семье по созданию условий для воспитания детей дошкольного возраста, охраны и укрепления их здоровья. $[3$, c. 9]

Технологии:

- проведение родительских собраний, семинаров - практикумов, консультаций;

- педагогические беседы с родителями (индивидуальные и групповые);

- встречи «за круглым столом»; 
- консультативная работа (использование СМИ, информационные стенды, тематические уголки и папки передвижки в группах);

- использование Интернет-ресурсов (размещение информации на сайте ДОУ, использование интерактивных форм взаимодействия);

- советы и рекомендации родителям, информировать о проводимых мероприятиях, отчитываться о проделанной работе и сообщать о своих успехах и победах в конкурсах и соревнованиях;

- работа с родителями по оформлению уголков Здоровья, папокпередвижек с материалом по формированию у детей привычки здорового образа жизни;

- разработка и распространение наглядных материалов (закладок, буклетов, листовок), с призывом вести здоровый образ жизни самим и приучать к этому своих детей.

Родители постоянные участники всех конкурсов, проводимых в дошкольном учреждении. Когда соблюдаются единые требования детского сада и семьи в вопросах воспитания, оздоровления, двигательной активности, гигиенических процедур, развития двигательных навыков, тогда будут правильно сформированы навыки здорового образа жизни у дошкольников. [1, c. 21]

Таким образом, разнообразие форм сотрудничества с семьей по проблеме здорового образа жизни позволяет привить детям чувство ответственности за своё здоровье, желание поддерживать спортивную форму и стремиться к достижению новых знаний и умений. Активизирую роль родителей через организацию совместной деятельности детей и взрослых, можно достичь наилучших результатов в физическом развитии и оздоровлении дошкольников. Ни одна, даже самая лучшая физкультурно-оздоровительная программа не сможет дать полноценных результатов, если она не решается совместно с семьей. Совместные занятия ребенка вместе с родителями спортом - один из основных аспектов воспитания.

Технология валеологического просвещения родителей позволяет не только на деле осуществить индивидуальный подход к каждому ребенку, но и привлечь родителей к совместным систематическим усилиям по оздоровлению детского организма в течение всего пребывания в дошкольном учреждении.

Таким образом, понимая особую актуальность проблемы, сохранение и укрепление здоровья дошкольников, формирование здорового образа жизни и воспитание культуры здоровья является главной задачей ДОУ.

Здоровый ребёнок- главная проблема ближайшего и отдалённого 
будущего. Поэтому весь потенциал, все перспективы социального и экономического развития должны быть направлены на сохранение здоровья детей как физического, так и интеллектуального. [1, с. 12]

Сохранение здоровья ребёнка, его социальная адаптация является делом актуальным и сложным. Надо в полной мере использовать здоровьесберегающие технологии для того, чтобы педагоги, дети и родители жили в состоянии эмоционального комфорта и высокого интереса к познанию, для того, чтобы дошкольник был здоров и социально адаптирован. [1, с. 12]

Внедрение в обучение здоровьесберегающих технологий ведет к снижению показателей заболеваемости детей, улучшение психологического климата в детских и педагогических коллективах, активно приобщает родителей дошкольников к работе по укреплению их здоровья. Используемые в комплексе здоровьесберегающие технологии формируют у дошкольника твердую мотивацию на здоровый образ жизни. [2, с. 16]

Подготовка к здоровому образу жизни ребенка на основе здоровьесберегающих технологий должна стать приоритетным направлением в деятельности каждого образовательного учреждения для детей дошкольного возраста. [2, с. 42]

\section{Список литературы}

1. Антонов Ю.Е., Кузницова М.Н., Саулина Т.Ф., «Здоровый дошкольник»: Социально- оздоровительные технологии 21 век., 2000

2. Гаврючина Л.В., «Здоровьесберегающие технологии в ДОУ»: Методическое пособие, 2008

3. Кудрявцев В.Т., Егоров Б.Б., «Развивающая педагогика оздоровления, программное» - методическое пособие, 2000

4. Лазарев М.Л., «Программа формирования здоровья детей дошкольного возраста», 1997

5. Овчинникова Т.С., «Организация здоровьесберегающей деятельности в дошкольных образовательных учреждениях», 2006

(C) О.М. Кириченко, 2022 